\title{
STUDI EVALUATIF IMPLEMENTASI PERILAKU SEHAT PADA SUKU ANAK DALAM DESA SIALANG KECAMATAN PAMENANG KABUPATEN MERANGIN JAMBI
}

\author{
Evaluative Study Of Health Behavior Implementation On Suku Anak Dalam In Sialang Village, \\ Pamenang Subdistrict Merangin District Jambi
}

\author{
M. Dody Izhar ${ }^{1}$, Fitria Eka Putri ${ }^{2}$
}

${ }^{1,2}$ Fakultas Kesehatan Masyarakat, Universitas Jambi

\begin{abstract}
ABSTRAK
Perilaku Hidup Bersih dan Sehat tatanan rumah tangga merupakan upaya pemberdayaan anggota rumah tangga baik di perkotaan, pedesaan maupun pada komunitas adat terpencil di Provinsi Jambi yang dikenal dengan Suku Anak Dalam untuk dapat berperilaku sehat. Jenis penelitian yang digunakan yaitu quasy experiment dengan one group pretest and posttest time series design. Populasi dalam penelitian ini adalah seluruh kepala keluarga Suku Anak Dalam Rombongan Ganta di Desa Sialang Kecamatan Pamenang Kabupaten Merangin Jambi sebanyak 14 KK dengan sampel total populasi. Analisis menggunakan metode $\mathrm{N}$-Gain score dan paired sample t test. Hasil menunjukkan bahwa Modul PHBS dikategorikan efektif terhadap perubahan perilaku sehat dengan nilai $\mathrm{N}$-Gain score sebesar 0,532 , dan berdasarkan analisis paired sample $t$ test diketahui bahwa ada perbedaan rata-rata skor peningkatan perilaku sehat sebesar 2,64 (pretest=2,59, posttest=5,23), dan berpengaruh secara signifikan $(p=0,000, t=15,43)$. Dengan demikian intervensi modul PHBS dengan cara aplikatif memberikan dampak perubahan perilaku sehat individu dan komunitas Suku Anak Dalam. PHBS sangat efektif untuk perubahan perilaku sehat dengan cara aplikatif dan pendampingan. Untuk adopsi perilaku sehat, PHBS perlu dilakukan secara konsisten, pemantauan berkala dan dukungan pelayanan kesehatan untuk komunitas Suku Anak Dalam. Kata Kunci: PHBS, Perilaku, SAD
\end{abstract}

\begin{abstract}
Clean and Healthy Behavior of the household order is an effort to empower household members both in urban, rural and remote indigenous communities in Jambi Province, known as Suku Anak Dalam to be able to behave in a healthy manner. The type of research used is quasy experiment with one group pretest and posttest time series design. The population in this study were all family heads of the Suku Anak Dalam in the Ganta Group in Sialang Village, Pamenang Subdistrict, Merangin District, Jambi with 14 families with a total population sample. Analysis using the N-Gain score method and paired sample $\mathrm{t}$ test. The results showed that the PHBS Module was categorized as effective against changes in healthy behavior with an $\mathrm{N}$-Gain score of 0,532 , and based on paired sample $t$ test analysis it was found that there were differences in the average score of increasing healthy behavior by 2.64 (pretest $=2,59$, posttest $=5,23)$, and significantly influence $(\mathrm{p}=0,000, \mathrm{t}=15.43)$. Thus the intervention of the PHBS module by applying it has an impact on the changes in the healthy behavior of individuals and the Suku Anak Dalam community. PHBS is very effective for changes in healthy behavior by applying and assisting. For the adoption of healthy behaviors, PHBS needs to be done consistently, periodic monitoring and support of health services for the Suku Anak Dalam community.
\end{abstract}

Keywords: PHBS, Behavior, SAD

Korespondensi: M. Dody Izhar

Email: mdodyizhar@unja.ac.id 
PENDAHULUAN

Sehat sebagai suatu keadaan yang sejahtera secara badan, jiwa dan sosial yang memungkinkan setiap orang hidup produktif secara sosial dan ekonomi. Berdasarkan Rencana Strategis Kementerian Kesehatan 2015-2019, Program Indonesia Sehat dilakukan dengan pendekatan keluarga menggunakan 10 indikator dalam pencapaian keluarga sehat yaitu keluarga mengikuti program Keluarga Berencana $(\mathrm{KB})$, persalinan oleh tenaga kesehatan, bayi mendapat imunisasi dasar lengkap, bayi mendapat ASI eksklusif, balita mendapatkan pemantauan pertumbuhan, penderita gangguan jiwa mendapat pengobatan dan tidak ditelantarkan, anggota keluarga tidak ada yang merokok, keluarga sudah menjadi anggota Jaminan Kesehatan Nasional (JKN), keluarga mempunyai akses sarana air bersih dan keluarga mempunyai akses atau menggunakan jamban sehat (1).

Perilaku Hidup Bersih dan Sehat adalah merupakan perilaku kesehatan yang dilakukan atas kesadaran sehingga anggota keluarga atau keluarga dapat menolong dirinya sendiri di bidang kesehatan dan berperan aktif dalam kegiatan-kegiatan kesehatan di masyarakat (2).

Provinsi Jambi merupakan Provinsi ke-6 terendah dengan proporsi rumah tangga (ruta) ber-PHBS di Indonesia yaitu sebesar 20\%, angka tersebut jauh dari target yang diharapkan dari cakupan ruta ber PHBS pada daerah perkotaan yang rata-rata nasional mencapai 42,3 \% dan rumah tangga ber PHBS daerah pedesaan yang jauh lebih rendah sebesar 22,9\%, ini dapat diartikan bahwa beberapa wilayah di Provinsi Jambi belum terpapar sosialisasi PHBS terlebih pada rumah tangga Orang Rimba/ Suku Anak Dalam (SAD) $(3,4)$.
Suku Anak Dalam (SAD) merupakan kelompok sosial budaya yang secara geografis bertempat tinggal di daerah terpencil dan lokal di Provinsi Jambi. Kondisi tersebut mengakibatkan keterbatasan dalam mengakses berbagai pelayanan sosial dasar seperti kesehatan, pendidikan, transportasi dan informasi yang datang dari luar komunitas mereka (5).

Suku Anak Dalam (SAD) di Provinsi Jambi berdasarkan data terakhir 2017 berjumlah $6.773 \mathrm{KK}$ atau 28.886 jiwa yang tersebar di 8 Kabupaten. Dari jumlah tersebut $3.489 \mathrm{KK}$ atau 14.947 Jiwa belum pernah sama sekali memperoleh pembinaan, dan yang sudah memperoleh pembinaan belum juga menampakan hasil yang signifikan (4).

Lingkungan budaya akan sangat mempengaruhi tingkah laku manusia, menghasilkan keragaman berperilaku, termasuk perilaku pola hidup bersih dan sehat. Perilaku hidup sehat masyarakat sangat ditentukan oleh sejauh mana pemahaman masyarakat tentang perilaku hidup sehat dan manfaatnya. Nilai-nilai tersebut dalam perspektif tafsir budaya dapat dikatakan sebagai kearifan lokal (local wisdom) masyarakat budaya yang berfungsi untuk memelihara kelangsungan dan pertumbuhan hidup mereka (6).

Pola hidup sehat meliputi gaya hidup, pola makan sehat, pemeriksaan kesehatan secara rutin, pengetahuan tentang kesehatan, Pola Hidup Bersih dan Sehat (PHBS) (7). Pola kebersihan diri yang meliputi kebersihan kulit, pakaian, mulut dan gigi, tangan dan kuku, alat reproduksi, telinga, rambut, dan kaki. Untuk pola istirahat juga penting guna menyeimbangkan waktu bekerja dan waktu luang. Dalam melaksanakan berbagai aktivitas, tubuh membutuhkan beberapa 
waktu untuk beristirahat yang bertujuan untuk menyembuhkan keletihan dengan rekreasi, istirahat dan tidur (8).

Untuk dapat bersosialisasi dengan masyarakat pada umumnya maka kebersihan diri merupakan salah satu faktor penghambat yang harus dilakukan perubahan-perubahan perilaku secara individu. Untuk itu perlu memberikan contoh perilaku sehat sehingga masyarakat SAD dapat berperilaku bersih dan sehat dalam kehidupan sehari-hari. Dengan demikian adapun tujuan dalam penelitian ini adalah untuk mengetahui perubahan perilaku sehat pada komunitas Suku Anak Dalam di Desa Sialang Kecamatan Pamenang Kabupaten Merangin Provinsi jambi dengan menggunakan 10 indikator dalam Perilaku Hidup Bersih dan Sehat (PHBS).

\section{METODE PENELITIAN}

Penelitian ini merupakan penelitian analitik dengan rancangan quasy experiment dengan one group pretest and posttest design. Dengan disain yang digunakan yaitu Time series (9). Tujuan penelitian ini adalah untuk mengetahui pengaruh penerapan PHBS terhadap perilaku sehat pada Suku Anak Dalam di Desa Sialang Kecamatan Pamenang Kabupaten Merangin Jambi yang dilaksanakan mulai bulan Mei s/d November 2019.

Populasi dalam penelitian ini adalah seluruh Kepala Keluarga yang memiliki anak yang berada di Rombong Ganta Suku Anak Dalam (SAD) Desa Sialang Kecamatan Pamenang Kabupaten Merangin. Jumlah populasi sebanyak 14 orang. Jumlah sampel sebanyak 14 orang.
Sampel diambil dengan teknik Total sampling $(10,11)$.

Instrumen yang digunakan pada penelitian ini yaitu Modul PHBS yang dikembangkan oleh Kementerian Kesehatan RI dan daftar tilik untuk observasi perubahan perilaku sehat subjek penelitian (1).

Analisa data yang dilakukan untuk melihat pengaruh perlakuan melalui persyaratan uji normalitas data dan untuk mengetahui efektivitas dan perbedaan sebelum dan sesudah perlakuan melalui rangkaian uji $\mathrm{N}$-Gain Score dan paired sample test $(12,13)$.

\section{HASIL PENELITIAN}

\section{Karakteristik subjek penelitian}

Karakteristik subjek penelitian memperlihatkan bahwa proporsi subjek penelitian sebagian besar adalah lakilaki yaitu 12 orang $(85,71 \%)$ sedangkan perempuan sebanyak 2 orang (14,29\%) dengan pekerjaan tetapnya adalah berburu $(85,71 \%)$ dan usia rata-rata (Mean \pm SD) : 42,93 \pm 13,84.

\section{Deskripsi data}

Adapun dari $14 \mathrm{KK} /$ rumah Suku Anak Dalam yang di wawancara dan observasi langsung oleh peneliti terhadap 10 klasifikasi PHBS selanjutnya sebagai informasi data yang di analisis pre-test maupun post-test, adapun gambaran perlakuan intervensi PHBS terhadap perilaku sehat pada Suku Anak Dalam dapat disampaikan sebagai berikut:

\section{a. Hasil pre test dan post test perilaku sehat SAD}

Distribusi frekuensi skor Pretest dan Post-test pada kelompok 
eksperimen dapat disampaikan dari

tabel berikut ini:

Tabel 1. Hasil Observasi dan Test Perilaku Sehat SAD Pre-Test dan Post-Test

\begin{tabular}{|c|c|c|c|c|c|c|c|c|c|c|c|}
\hline \multirow{2}{*}{$\begin{array}{c}\text { No } \\
\text { Rumah }\end{array}$} & \multirow{2}{*}{$\begin{array}{c}\text { Kode Subjek } \\
\text { (KK) }\end{array}$} & \multicolumn{5}{|c|}{ Pengukuran (Pre-Test) } & \multicolumn{5}{|c|}{ Pengukuran (Post-Test) } \\
\hline & & O1 & $\mathbf{O 2}$ & $\mathbf{O 3}$ & O4 & Rerata & 05 & 06 & O7 & $\mathbf{0 8}$ & Rerata \\
\hline 1 & $\mathrm{Ga}$ & 2 & 2 & 3 & 5 & 3 & 3 & 6 & 6 & 7 & 5,5 \\
\hline 2 & Fir & 2 & 2 & 4 & 4 & 3 & 3 & 4 & 5 & 6 & 4,5 \\
\hline 3 & $\mathrm{Bi}$ & 3 & 2 & 3 & 4 & 3 & 2 & 4 & 6 & 7 & 4,75 \\
\hline 4 & $\mathrm{Li}$ & 2 & 2 & 3 & 4 & 2,75 & 3 & 5 & 6 & 7 & 5,25 \\
\hline 5 & $\mathrm{Si}$ & 2 & 2 & 2 & 3 & 2,25 & 4 & 6 & 7 & 7 & 6 \\
\hline 6 & $\mathrm{Ra}$ & 2 & 2 & 2 & 2 & 2 & 2 & 5 & 6 & 6 & 4,75 \\
\hline 7 & Mi & 2 & 2 & 3 & 3 & 2,5 & 3 & 4 & 7 & 7 & 5,25 \\
\hline 8 & Gn & 2 & 2 & 2 & 4 & 2,5 & 3 & 5 & 6 & 7 & 5,25 \\
\hline 9 & $\mathrm{Ba}$ & 2 & 2 & 3 & 3 & 2,5 & 3 & 3 & 6 & 7 & 4,75 \\
\hline 10 & $\mathrm{Tt}$ & 2 & 3 & 3 & 4 & 3 & 4 & 6 & 6 & 6 & 5,5 \\
\hline 11 & $\mathrm{Ng}$ & 2 & 2 & 4 & 4 & 3 & 4 & 4 & 6 & 7 & 5,25 \\
\hline 12 & $\mathrm{Ja}$ & 2 & 2 & 2 & 2 & 2 & 3 & 5 & 6 & 7 & 5,25 \\
\hline 13 & Fh & 2 & 2 & 2 & 3 & 2,25 & 4 & 6 & 7 & 7 & 6 \\
\hline 14 & Th & 2 & 2 & 2 & 4 & 2,5 & 3 & 5 & 6 & 7 & 5,25 \\
\hline Jumlah & & 29 & 29 & 38 & 49 & 36,25 & 44 & 68 & 86 & 95 & 73,25 \\
\hline Rerata & & 2,07 & 2,07 & 2,71 & 3,5 & 2,59 & 3,14 & 4,86 & 6,14 & 6,79 & 5,23 \\
\hline
\end{tabular}

Berdasarkan data pada Tabel 1, diperoleh hasil dari penilaian observasi langsung selama 4 hari (time series) skor sesudah perlakuan sebesar 5,23, ada selisih perbedaan skor perilaku sehat sebesar 2,64 bila dibandingkan dengan skor observasi sebelum perlakuan PHBS hanya sebesar 2,59.

\section{b. Hasil observasi berdasarkan indikator PHBS}

Berdasarkan 10 indikator PHBS tatanan rumah tangga dapat disampaikan hasil sebagai berikut :

Tabel 2. Rekapitulasi Pre-test dan Post-test berdasarkan 10 Indikator PHBS

\begin{tabular}{|c|c|c|c|c|}
\hline \multirow{2}{*}{ No } & \multirow{2}{*}{ Indikator } & \multicolumn{2}{|c|}{ Perlakuan } & \multirow{2}{*}{ Selisih } \\
\hline & & Pre-test & Post-test & \\
\hline 1 & Persalinan ditolong oleh tenaga kesehatan & 0 & 0 & 0 \\
\hline 2 & Memberi bayi ASI Eksklusif & 0 & 0 & 0 \\
\hline 3 & Menimbang bayi dan balita & 0 & 0 & 0 \\
\hline 4 & Menggunakan air bersih & 56 & 56 & 0 \\
\hline 5 & Mencuci tangan dengan air bersih dan sabun & 4 & 35 & 31 \\
\hline 6 & Menggunakan jamban sehat & 55 & 55 & 0 \\
\hline 7 & Memberantas jentik di rumah & 2 & 39 & 37 \\
\hline 8 & Makan buah dan sayur setiap hari & 2 & 22 & 20 \\
\hline 9 & Melakukan aktivitas fisik setiap hari & 4 & 41 & 37 \\
\hline 10 & Tidak merokok di dalam rumah & 22 & 45 & 23 \\
\hline \multicolumn{2}{|c|}{ Jumlah } & 145 & 293 & 148 \\
\hline \multicolumn{2}{|c|}{ Rerata } & 2,59 & 5,23 & 2,64 \\
\hline
\end{tabular}


Berdasarkan deskripsi hasil intervensi PHBS terhadap selisih rerata perubahan perilaku maka diasumsikan intervensi yang telah dilakukan memberikan dampak terhadap perubahan perilaku. Oleh karena itu data tersebut selanjutnya dilakukan uji normalitas data dengan metode onesample kolmogorov-smirnov test sebagai prasyarat uji paired sample $t$ test. Hasil perhitungan uji normalitas data pre-test dan post-test diketahui bahwa skor perilaku sehat sebelum perlakuan (Pre-test) nilai Sig. 0,504, dan skor perilaku sehat sesudah perlakuan (Post-test) nilai Sig. 0,447, disimpulkan bahwa data berdistribusi normal.

3. Evaluasi dan pengaruh intervensi PHBS terhadap perilaku sehat pada SAD

\section{a. Evaluasi intervensi PHBS terhadap perilaku sehat}

Untuk mengevaluasi intervensi modul PHBS yang dilakukan dapat di lihat dari tingkat efektivitas peningkatan perilaku sehat dengan menghitung nilai $N$-Gain score yaitu diperoleh dari data rata-rata skor pretest dan post-test. Rata-rata $N$-Gain Score dapat disajikan sebagai berikut:

Tabel 3. N-Gain Score Pre-Test dan Post-Test

\begin{tabular}{|c|c|c|c|c|}
\hline Metode & \multicolumn{2}{|c|}{$\begin{array}{c}\text { Perolehan } \\
N \text {-Gain Score }\end{array}$} & N-Gain & Kategori \\
\hline \multirow{2}{*}{ Pre-test } & $\mathrm{O} 1$ & $\mathrm{O} 4$ & \multirow{2}{*}{0,180} & \multirow{2}{*}{ Rendah / Kurang Efektif } \\
\hline & 2.07 & 3,5 & & \\
\hline \multirow{2}{*}{ Post-test } & O5 & $\mathrm{O} 8$ & \multirow{2}{*}{0,532} & \multirow{2}{*}{ Sedang / Efektif } \\
\hline & 3,14 & 6,79 & & \\
\hline
\end{tabular}

Berdasarkan Tabel 3 diketahui bahwa pengukuran/observasi perubahan perilaku kesehatan setelah perlakuan/pemberian Modul PHBS (Post-Test) memperoleh nilai $\mathrm{N}$-Gain lebih tinggi yaitu sebesar $0,532(53,2 \%)$ dengan kategori sedang/efektif dibandingkan dengan sebelum perlakuan pemberian Modul PHBS (Pre-Test) dengan nilai $N$-Gain sebesar 0,180 (18\%). Dengan demikian eksperimen pemberian informasi dan praktik melalui Modul PHBS efektif dalam merubah perilaku kelompok/rombong Ganta (Suku Anak Dalam) tentang perilaku sehat.

\section{b. Pengaruh intervensi PHBS terhadap perilaku sehat}

Berdasarkan hasil analisis Paired Sample Test pada data pre-test dan posttest diketahui ada perbedaan peningkatan skor perilaku sehat. Adapun ringkasan uji dapat disampaikan pada Tabel 4 berikut: 
Tabel 4. Analisis Pengaruh Intervensi PHBS terhadap Perilaku Sehat Suku Anak Dalam di Desa Sialang Kec. Pamenang Kab. Merangin

\begin{tabular}{|c|c|c|c|c|c|}
\hline \multirow{2}{*}{\multicolumn{2}{|c|}{ Statistics }} & \multicolumn{4}{|c|}{ Paired Differences } \\
\hline & & Mean & SD & $\mathbf{t}$ & Sig. (2-tailed) \\
\hline Pre-test & 2,59 & \multirow{2}{*}{2,64} & \multirow{2}{*}{0,64} & \multirow{2}{*}{15,43} & \multirow{2}{*}{0,000} \\
\hline Post-test & 5,23 & & & & \\
\hline
\end{tabular}

Berdasarkan hasil uji Paired Sample Test diketahui rata-rata pre-test sebesar 2,59 pada saat post-test meningkat menjadi 5,23, sehingga peningkatannya sebesar 2,64. Selanjutnya berdasarkan uji Paired Sample Test didapatkan $\mathrm{t}$ hitung sebesar 15,43 dengan signifikansi 0,000. Nilai t tabel pada $(d f: \mathrm{n}-\mathrm{k})=13$, dengan taraf signifikansi $5 \%$ adalah 2,16. Jadi nilai t hitung > t tabel $(15,43>2,16)$ dan nilai signifikansinya kurang dari 0,05 ( $p=$ $0,000<0,05)$. Dari data diatas dapat disimpulkan bahwa terdapat perbedaan perilaku sehat antara sebelum dan sesudah intervensi PHBS

\section{PEMBAHASAN}

PHBS tatanan rumah tangga adalah upaya untuk memberdayakan anggota rumah tangga agar sadar, mau dan mampu mempraktekkan PHBS untuk memelihara dan meningkatkan kesehatannya, mencegah risiko terjadinya penyakit dan melindungi diri dari ancaman penyakit serta berperan aktif dalam gerakan kesehatan masyarakat (1).

Perilaku pada diri seseorang tidak terlepas dari faktor-faktor yang menentukan perilaku tersebut. Dapat dipahami bahwa pemberian intervensi promosi kesehatan dapat berpengaruh terhadap perubahan perilaku ke arah yang lebih baik (14).

Pada penelitian pemberian intervensi PHBS yang telah dilakukan diketahui bahwa anggota SAD hampir sebagian besar sudah mau dan mampu mempraktekkan langsung beberapa indikator PHBS. Intervensi yang didasari oleh aplikasi langsung dapat memberikan dampak perubahan yang lebih baik. Dengan demikian intervensi PHBS begitu efektif terhadap perilaku sehat, ini sesuai dengan analisa nilai $N$-Gain Score nya sebesar $53,2 \%$.

Berdasarkan nilai $N$-Gain Score tersebut maka masih dimungkinkan peningkatan perubahan perilaku perlu penambahan media lain dalam peningkatan intensitas pemahaman dan perubahan perilaku seseorang, efektifitas penyampaian pesan informasi sangat efektif bila ada kombinasi melalui media (alat peraga atau demonstrasi) secara langsung (15).

Berdasarkan teori StimulusOrganism-Respons, menyatakan bahwa perubahan perilaku tergantung stimulus terhadap organisme, oleh karena itu bila stimulus diperkuat atau dimunculkan akan meningkatkan perhatian, pengertian, penerimaan dan bereaksi dan akhirnya bertindak (16).

Perbedaan nilai rata-rata praktek menggunakan analisis uji $\mathrm{t}$ berpasangan (paired sample t-test) menunjukkan bahwa ada perbedaan yang signifikan perlakuan PHBS antara sebelum dan sesudah mendapat intervensi. Hal ini dapat dilihat dari hasil nilai uji statistik yang diperoleh dengan nilai $p$ value sebesar 2,64, yang artinya bahwa ada selisih peningkatan perilaku kesehatan. Hasil analisis tingkat 
signifikansi yang dihasilkan pada variabel praktek antara sebelum dan sesudah dilakukan intervensi diperoleh nilai $p$ value sebesar 0,000. Hal itu menunjukkan bahwa ada pengaruh pemberian intervensi PHBS terhadap perilaku kesehatan Suku Anak Dalam di Desa Sialang Kecamatan Merangin Kabupaten Merangin Jambi.

Hasil penelitian serupa menunjukkan bahwa penggunaan media audio visual sangat efektif dalam perubahan perilaku sehat, tingkat pengetahuan sesudah diberikan pendidikan kesehatan PHBS dengan media video sebagian besar responden berada dalam kategori baik. Hal ini dikarenakan adanya pengaruh sebelum dan sesudah pendidikan kesehatan ( $p$ : 0,001) (17).

Sedangkan hasil penelitian lain menyatakan bahwa beberapa indicator PHBS yang belum tercapai pada perubahan perilaku sehat pada masyarakat pedesaan berdasarkan indikator yaitu status kepemilikan jamban yang masih kurang dan kurangnya konsumsi sayur dan buah sehingga perlunya upaya yang nyata berupa penyuluhan dan pendampingan terhadap perubahan perilaku (18).

Pendapat lain menyatakan bahwa pengukuran perubahan perilaku anak-anak pada masyarakat terpencil dan negara non industri dapat dinyatakan dalam sebuah instrumen yaitu berdasarkan Status Sosial Subjektif (SSS) MacArthur. Instrumen ini dinilai sangat konsisten dapat menilai perubahan perilaku dan dijadikan sebagai prediktor perilaku dari faktor psikologis dan fisiologis (19).

Indikator status sosial ekonomi, perilaku kesehatan dan riwayat kesehatan penting untuk mengevaluasi populasi kesehatan dan indikator yang terkait dengan keadaan alamiah, dijadikan sebagai penentu kesehatan bagi masyarakat adat.
Kesehatan pengawasan anak-anak muda, yang mewakili masyarakat yang paling rentan, dapat memberikan data yang bermakna mengenai pencapaian suatu awal sehat yang optimal dalam hidup (20).

Perilaku kesehatan merupakan hasil dari beberapa pengalaman dan hasil observasi yang terjadi di lapangan (masyarakat) bahwa perilaku seseorang termasuk terjadinya perilaku kesehatan, diawali dengan pengalaman-pengalaman seseorang serta adanya faktor eksternal (lingkungan fisik dan non fisik). Pengalaman dan lingkungan tersebut kemudian diketahui, dipersepsikan atau diyakini seseorang sehingga menimbulkan motivasi untuk bertindak yang akhirnya diwujudkan dengan perilaku, termasuk perilaku sehat $(21,22)$.

Perilaku/tindakan individu dan kelompok dipengaruhi oleh tiga sistem yaitu sistem sosial, sistem budaya dan sistem kepribadian masing-masing individu. Di dalam suatu sistem sosial, individu menduduki suatu tempat (status) dan bertindak (berperan) sesuai dengan norma atau aturan yang berlaku (23). Hal ini sesuai dengan temuan di lapangan yang mengatakan bahwa warga kelompok Temenggung Ganta mengikuti kerja bakti yang diadakan sesuai dengan yang diinstruksikan oleh Temengung nya, karena Temenggung adalah seseorang yang memiliki kuasa dan status sosial tinggi memberikan instruksi kepada warganya untuk mengikuti kerja bakti sehingga warga melaksanakan kegiatan kerja bakti. Sistem budaya mempengaruhi individu dalam perilaku pengambilan keputusan berobat, hal ini diperkuat dengan temuan data dimana seseorang yang memberikan pengaruh dalam pengambilan keputusan berobat adalah diri sendiri dan suami/istri. 
Sebagian besar masyarakat Suku Anak Dalam masih perlu ditingkatkan kemampuan dalam menjaga kebersihan diri, kebersihan lingkungan pemukiman, gizi dan tumbuh kembang anak. Masyarakat SAD di Desa Sungai Terap memiliki kebiasaan berpindah-pindah pemukiman. Mereka hidup berkelompokkelompok, akses jalan sangat sulit untuk mencapai lokasi pemukiman. Dengan kondisi tersebut maka upaya pemberdayaan bidang Kesehatan adalah memadukan konsep promotif dan preventif, kuratif serta pengobatan tradisional (24).

Melihat perbandingan PHBS mahasiswa pre dan post PBL tampak ada perubahan persentase tiap kategori, pada post PBL tidak ada lagi mahasiswa yang tergolong kategori cukup namun justru kategori sangat baik menurun persentasenya. Hal ini mungkin terjadi karena PHBS mahasiswa hanya ditilik dengan angket tanpa melalui observasi kebiasaan hidup sehat mereka sehari-hari yang mencerminkan perilaku mereka. Perilaku adalah bentuk respons atau reaksi terhadap stimulus atau rangsangan dari luar organisme (orang), sehingga dalam memberikan respons sangat tergantung pada karakteristik atau faktor-faktor lain dari orang yang bersangkutan. Hal ini berarti meskipun stimulusnya sama bagi beberapa orang, namun respons dari tiaptiap orang berbeda. Faktor lingkungan ini sering merupakan faktor yang dominan yang mewarnai perilaku seseorang (25).

Jelas bahwa subjek penelitian Suku Anak Dalam sebagai raw input dalam intervensi memiliki faktor internal dan eksternal yang berbeda-beda. Keadaan tersebut menyatakan perilaku seseorang dipengaruhi faktor keturunan, badaniah, psikologik dan sosial. Kegiatan PHBS tentang perilaku sehat untuk mengembangkan karakter pemberdayaan masyarakat, keluarga dan individu yang merupakan faktor sosial (26).

Teori perubahan perilaku juga menjadi bagian yang penting dalam masalah pembentukan perubahan perilaku sebelum dan sesudah PHBS, dalam hal ini Teori Stimulus Organisme relevan dalam rumusan masalah ini karena didasarkan pada asumsi bahwa penyebab terjadinya perubahan perilaku tergantung pada kualitas rangsang (stimulus) yang berkomunikasi dengan organisme berupa perhatian, pengertian, dan penerimaan yang nantinya akan menimbulkan reaksi atau perubahan sikap dari masyarakat untuk mengolah stimulus sehingga terjadi kesediaan untuk bertindak demi stimulus yang diterimanya selanjutnya dengan dukungan fasilitas serta dorongan dari lingkungan maka stimulus mempunyai efek reaksi (perubahan praktek) dari individu (27).

Upaya mengedukasi masyarakat untuk menerapkan pola hidup bersih dan sehat, seharusnya menjadi perhatian semua sektor pemerintah dan masyarakat. Pendamping diharapkan dapat berperan optimal dalam mendampingi masyarakat untuk melakukan perubahan perilaku ini. Harapannya paradigma tersebut bisa diubah, pendamping kesehatan masyarakat dan pendamping masyarakat diharapkan dapat bersinergi untuk bisa mengubah perilaku masyarakat tersebut (6).

Dalam melakukan sebuah perubahan, terlebih adalah perilaku, tampaknya tidak cukup dilakukan dengan usaha yang biasa namun dibutuhkan praktis langsung (28). Mendampingi warga Suku Anak Dalam memerlukan pendamping, menyiapkan strategi dan aktivitas-aktivitas penunjang dalam mencapai goals tersebut. Mengedukasi masyarakat tentang pola 
hidup bersih dan sehat, serta membuat mereka mau melakukan pola hidup bersih dan sehat perlu pendampingan yang optimal. Namun, ini menjadi tantangan tersendiri bagi pendamping dan manajemen (29).

Kedekatan keberadaan unit pelayanan kesehatan hendaklah menjangkau kepada komunitas adat terpencil sehingga memudahkan proses umpan balik bagi Suku Anak Dalam dalam mendapatkan pelayanan kesehatan dengan secara tidak langsung perlahan-lahan dapat meningkatkan pemahaman dan adopsi perilaku hidup bersih dan sehat (PHBS) dan mengikis kepercayaan setempat terkait kesehatan dan religi (30).

Peran pemerintah dalam hal ini petugas kesehatan adalah memegang peranan penting dalam perubahan perilaku kesehatan, dikarenakan lokasi Suku Anak Dalam di Desa Sialang belum secara langsung dan rutin mendapatkan pelayanan kesehatan, selama ini berdasarkan pada situasi apabila Suku Anak Dalam mengalami kesakitan saja. Pencapaian perubahan perilaku merupakan proses yang berkelanjutan mengingat mitos atau keyakinan yang diturunkan turun temurun dari Suku Anak Dalam mungkin bisa dengan sangat cepat luntur akibat proses akulturasi, dalam arti proses pendampingan petugas kesehatan dengan melibatkan komunitas itu sendiri $(31,32)$.

Perilaku seseorang merupakan suatu hal yang dipengaruhi oleh beberapa aspek meliputi adat, sikap, emosi, nilai, etika, kekuasaan, persuasi, dan atau genetika. Perilaku sendiri penting dan berengaruh dalam kesehatan, terutama tentang perilaku hidup sehat. Perilaku yang positif akan berdampak positif pula bagi kesehatan individu. Perilaku yang sehat sangat mempengaruhi kualitas dan taraf hidup seseorang agar dapat menjadi lebih baik dan sejahtera (33).

\section{KESIMPULAN}

Implementasi perilaku hidup bersih dan sehat (PHBS) yang telah dilaksanakan dapat berjalan dengan efektif ditandai dengan perubahan perilaku sehat. Ada pengaruh perilaku hidup bersih dan sehat (PHBS) terhadap perilaku sehat pada Suku Anak Dalam di Desa Sialang Kecamatan Pamenang Kabupaten Merangin Jambi. Perlu pendampingan yang lebih intensif dan pembentukan pelayanan terpadu kesehatan untuk memonitor perilaku sehat dalam kehidupan sehari-harinya.

\section{ACKNOWLEDGEMENT}

Pada kesempatan ini peneliti mengucapkan terima kasih kepada Rektor Universitas Jambi telah memberikan izin dan dana penelitian yang bersumber dari Dana DIPA-PNBP Nomor: 042.01.2.400950/2019.

\section{DAFTAR PUSTAKA}

1. Kementerian Kesehatan RI. Pedoman Pembinaan Perilaku Hidup Bersih dan Sehat (PHBS). In: Peraturan Menteri Kesehatan Republik Indonesia No 2269/MENKES/PER/XI/2011. Jakarta; 2011.

2. Maryunani A. Perilaku Hidup Bersih dan Sehat (PHBS). Jakarta: Trans Info Media; 2013.

3. Kementerian Kesehatan RI. Rencana Strategis Kementerian Kesehatan Tahun 2015-2019. In: Keputusan Menteri Kesehatan RI Nomor HK0202/MENKES/52/2015. Jakarta; 2015.

4. Disosnakertrans Provinsi Jambi. Profil Komunitas Adat Terpencil (KAT) Program Pemberdayaan KAT di Propinsi Jambi. Jambi; 2018. 
5. Hasan I. Pemberdayaan Sosial Ekonomi Komunitas Adat Terpencil (KAT) Dalam Rangka Pengentasan Kemiskinan. J Sosiol USK (Media Pemikir Apl. 2013;3(1):77-91.

6. Sagrim M, Noor NN, Thaha R, Maidin A. Kearifan Lokal Komunitas Adat Terpencil Suku Taburta Dalam Perilaku Hidup Bersih Dan Sehat Berbasis Rumah Tangga. Media Kesehat Masy Indones Univ Hasanuddin. 2015;11(4):218-27.

7. Pratiwi AS. Penilaian Promosi Kesehatan Serta Pola Hidup Sehat Tenaga Kerja HSM Dan PP3 P.T. Krakatau Steel Sebagai Upaya Meningkatkan Derajat Kesehatan Tenaga Kerja. Jakarta; 2009.

8. Hardinge, M.G \& Shryock H. Kiat Keluarga Sehat Mencapai Hidup Prima dan Bugar. I. Bandung: Indonesia Publishing House; 2001.

9. Sugiyono. Metode Penelitian Kuantitatif Kualitatif dan R\&D. Bandung: Alfabeta; 2016.

10. Sastroasmoro, S \& Ismael S. DasarDasar Metode Penelitian Klinis. Jakarta: Binarupa Aksara; 2011.

11. Lemeshow, S. \& David J. Besar Sampel dalam Penelitian Kesehatan (terjemahan). Yogyakarta: Gadjah Mada University Press; 1997.

12. Hake RR. Analyzing change/gain scores. Unpubl URL http//www physics indiana edu $\wedge \sim$ sdi/AnalyzingChange-Gain pdf. 1999;16(7):1073-80.

13. Arikunto S. Statistika untuk Penelitian. Jakarta: Alfabeta; 2006.

14. Green, L. \& Kreuter M. Health Program Planning: An Educational and Ecological Approach. 4th editio. New York: McGraw Hill; 2005.

15. Wakefield MA, Loken B, Hornik RC. Use of mass media campaigns to change health behaviour. Lancet (London, England). 2010 Oct;376(9748):1261-71.

16. Skinner BF. Science and Human Behaviour. New York: Free Press
Collier-Macmillan; 1996.

17. Mulyadi MI, Warjiman, Chrisnawati. Efektivitas Pendidikan Kesehatan Dengan Media Video Terhadap Tingkat Pengetahuan Perilaku Hidup Bersih Dan Sehat. J Keperawatan STIKES Suaka Insa. 2018;3(2):1-9.

18. Natsir MF. Perilaku Hidup Bersih Dan Sehat (PHBS) Pada Tatanan Rumah Tangga Masyarakat Desa Parang Baddo. J Nas Ilmu Kesehat ( JNIK ). 2019;1(3):54-9.

19. Amir D, Valeggia C, Srinivasan M, Sugiyama LS, Dunham Y. Measuring subjective social status in children of diverse societies. PLoS One. 2019;14(12).

20. Egeland GM, Faraj N, Osborne G. Circumpolar Special Issue: Human Health at the Ends of the Earth Egeland GM, Faraj N, Osborne G Cultural, socioeconomic, and health indicators among Inuit preschoolers: Nunavut Inuit. Rural Remote Health [Internet]. 2007;10:2010. Available from: http://www.rrh.org.au

21. Notoatmodjo S. Promosi Kesehatan, Teori dan Aplikasi. Jakarta: PT. Rineka Cipta; 2010.

22. Izhar, M.D. \& Hubaybah H. Uji Coba Algoritma MTBS Dalam Kartu Deteksi Penyakit Pada Balita Suku Anak Dalam Desa Hajran Kecamatan Batin XXIV Kabupaten Batanghari Jambi. J Kesmas Jambi. 2019;3(1):18.

23. Parsons, T. dalam Supardan D. Pengantar Ilmu Sosial: Sebuah Kajian Pendekatan Struktural. Jakarta: Bumi Aksara; 2011.

24. Ridwan M\&, Lesmana O. Model Pemberdayaan Suku Anak Dalam Bidang Kesehatan Di Kecamatan Batin XXIV Kabupaten Batanghari. J Kesmas Jambi [Internet]. 2018;2(2):97-103. Available from: file:///C:/Users/User/Downloads/6558 -Article Text-14437-1-10-20190330 (1).pdf

25. Brempong, EA., Okyere, P., Cross, R 
\& Adjei R. Health Behaviour Change: Advancing the Utility of Motivational Interviewing(MI) to Health Promotion. J Addict Res Ther. 2013;04(05).

26. Maramis WF. Catatan Ilmu Kedokteran Jiwa. Surabaya: Airlangga University Press; 1990.

27. Salem KA, Balahmar MK, Milaat W, Gabal MS. The effects of a training program on knowledge, attitude and practice of the staff of primary health care centers towards growth monitoring: an intervention study. $\mathrm{J}$ Egypt Public Health Assoc. 1999;74(5-6):627-49.

28. Krianto T. Perilaku Hidup Bersih Sehat dengan Pendekatan Partisipatif. Kesmas Natl Public Heal J. 2009;3(6):254.

29. Suradi. Kebijakan Pemberdayaan Sosial Komunitas Adat Terpencil. Jakarta: P3KS Press.; 2013.
30. Triratnawati A. Dominasi Medis Modern Atas Medis Tradisional Suku Sumuri, Teluk Bintuni, Papua Barat. Masyarakat, Kebud dan Polit. 2017;30(2):174.

31. Chongsuvivatwong V, Phua KH, Yap MT, Pocock NS, Hashim JH, Chhem $\mathrm{R}$, et al. Health and health-care systems in southeast Asia: Diversity and transitions. Lancet [Internet]. 2011;377(9763):429-37. Available from:

http://dx.doi.org/10.1016/S01406736(10)61507-3

32. Laksono AD, Faizin K. Traditions Infl Uence Into Behavior in Health Care (Ethnographic Case Study on Health Workers Muyu Tribe). Bul Penelit Sist Kesehat. 2015;18(4).

33. Adliyani ZO. Pengaruh Perilaku Individu terhadap Hidup Sehat. Majority. 2015;4(7):109-14. 